DUYGU ÜLKER, Ph.D. Candidate ${ }^{1}$

E-mail: duygu.ulker@istanbul.edu.tr

BİRSEN KOLDEMIR, Ph.D. ${ }^{2}$

(Corresponding author)

E-mail: bkr@iuc.edu.tr

${ }^{1}$ Department of Marine Environment

Institute of Marine Sciences and Management

Istanbul University

No.17, Müşküle Street, 34134, Vefa-Fatih/Istanbul, Turkey

2 Department of Maritime Transportation Management

Engineering, Faculty of Engineering

Istanbul University-Cerrahpasa

34320, Avcilar/Istanbul, Turkey
Traffic Management Original Scientific Paper Submitted: 15 Nov. 2020

Accepted: 16 Mar. 2021

DOI: $10.7307 /$ ptt.v33i5.3746

\title{
COMPARATIVE VOYAGE-BASED EVALUATION OF YACHT TRANSFER BY SELF-SAILING AND CARGO VESSEL SHIPMENT - A PILOT STUDY
}

\begin{abstract}
Directional seasonal domestic yacht traffic in Turkey takes place from the coasts of the Marmara Sea to the south coasts of Turkey at the beginning of the summer, and the traffic in the opposite direction occurs at the end of the summer/beginning of the autumn. Considering the long distance and long sailing time along the routes of seasonal yacht moving, this study reveals whether yacht-carrying using domestic shipping can be feasible for yacht owners and ship-owners. Two groupings of port and ship selection criteria are indicated for yacht carrying: technical criteria and management criteria. Estimations are performed for selected sample ship and yacht model and selected loading/discharging ports. All of the voyage expenses are formulated and written in MatLab. The voyage costs of the sample ship and yacht model are estimated to evaluate the feasibility of yacht-carrying between the Bodrum and Haydarpaşa ports. Whether the cost of yacht-carrying between the ports is acceptable depends on the number of yachts carried, the speed of yachts, and the yachts' type. The long coastline and current yacht traffic potential of Turkey mean that it is more effective to carry yachts on domestic shipping lines.
\end{abstract}

\section{KEYWORDS}

efficiency; shipping; voyage cost; yacht carrying; yacht traffic.

\section{INTRODUCTION}

The long coastline of Turkey offers huge potential for shipping and yacht tourism between the multiple Turkish ports and marinas. However, the Black Sea coast of Turkey does not have the capacity for these sectors due to geographic, environmental, and socio-economic factors. Consequently, major yacht tourism activities exist between the Istanbul Strait, the Sea of Marmara, and the Mediterranean coastal areas in Turkey [1-4].

Sailing by yacht is generally done for pleasure [5]. If the sailing occurs for transportation purposes only, yacht owners may prefer to have the yacht carried by a merchant ship like transport in international shipping [6]. Particular factors cause yacht carrying to be preferable to sailing, including long distances, insufficient time, a lack of experience in sailing, and technical and safety factors. For these reasons yacht owners in Turkey have created a demand for yacht carrying between the Turkish ports, especially for the sailing from south to north at the end of the summer. Weather conditions and sailing risks both play a role in this demand. The statistics from the Ministry of Transportation and Infrastructure of the Republic of Turkey show that the Turkish Straits Sea Area poses the highest risk of accidents in Turkey [7].

In international shipping, Turkey generally imports yachts from the USA, Europe, and the Far East and some of the major yacht loading and discharging ports in Turkey are TCDD Haydarpaşa Port, Ambarlı Port, Limaş Port, Fethiye, Bodrum, Marmaris Cruise Port, Mersin International Port (MIP), and the Port of Akdeniz [7]. Each port has different tariffs for services such as pilotage, tugboats, mooring boats, cargo handling, etc. 
Maritime transportation must factor in the needs and activities of organisations and professional activities such as ship-owners, shippers, port and terminals, shipping agencies, cargo handling, and lashing operations. [8]. In the light of the above information, this study considered the Turkish Maritime Policy and evaluated the technical and economic efficiency of a yacht being carried between the Turkish ports to evaluate the supply offered by ship-owners and the demand existing from the yacht owners. As indicated by Fagertholt et al. (2013), "a project shipping company needs an engineering unit to calculate the feasibility of transporting their cargoes with respect to shape, stability, weight, and the ships' heavy lifting capacities." [12]. These evaluations are necessary for yacht shipping regardless of whether it takes place as international or domestic transport. In this study, a sample ship model which carries the yachts and a sample yacht model to be loaded on board are selected considering the technical and management criteria mentioned above.

This paper has scenario-based calculations which are voyage cost estimations of a ship (Scenario 1) and yacht sailing cost estimations (Scenario 2) between the same origin and destination ports, to compare the unit cost of yacht carrying with the cost of yacht sailing. This paper reveals the efficiency of yacht carrying between the origin and destination ports. The costs are formulated and the cost estimation model is written in MatLab. The model shows how many yachts are to be carried to provide cost-effectiveness compared with yacht sailing expenses. Although this model is applied to the Bodrum and Haydarpaşa domestic route, it can be modified for the other domestic or international routes to reveal the efficiency of yacht carrying. This study, a first of its kind on yacht carrying and its efficiency, provides a contribution to the literature for a specific cargo type.

The structure of the rest of the paper is as follows: A literature review about the yacht tourism/ traffic potential of Turkey and voyage cost estimation factors are given in Section 2. The methodological framework of the study is given in Section 3. The selected route for the ship voyage and yacht sailing cost estimation is given in Section 3.1. The ship selection criteria for the yacht carrying on a domestic line and the specifications of the selected ship are presented in Section 3.2. Specifications of the selected sample yacht model are presented in Section 3.3. The ship's voyage cost and yacht sailing cost estimations are given in Section 3.4 and 3.5 , respectively. Results and discussion, including comparison of the costs, are given in Section 4. Implications of the applied methodology, limitations of the study, and recommendation for further research are offered in Section 5.

\section{LITERATURE REVIEW}

The forecasted distribution of berthing space demand for yachts reveals that the potential of the Black Sea Coasts of Turkey will not change significantly by 2030 . The south coasts of Turkey, with its increasing yacht tourism potential, will remain the most intensive yacht tourism area in Turkey [1]. The population of the Aegean and Mediterranean coastal areas increases three to ten-fold during the summer months [9]. The increase of yacht tourism activity in the Aegean Sea and around the Mediterranean coast of Turkey in the summer period reflects this increase in tourist numbers even though it does not have a significant share in total tourism revenue [10, 11]. Moreover, the study by Aydoğan and Kadıoğlu (2018) revealed the positive correlation between tourism and yacht tourism in Turkey and indicated that Muğla is the district attracting the most visits from domestic and foreign yachts. Most of the yacht owners move their yacht to the Aegean and Mediterranean coasts at the beginning of summer and back again to the coasts of the Marmara Sea at the end of the season. North to south sailing in summer is easier than south to north sailing at the end of the summer or the beginning of the autumn because of the weather and navigational conditions.

Due to the economic and technical considerations, decision support tools based on shipping operations research appear more frequently [12]. Shipping companies use a wide variety of practices and equipment both in ship/cargo types and at loading/ discharging ports, and this means that decision support models require special adaptations to be made on the cargo/ships [13-15].

In international shipping, yachts are carried by general cargo, container, multi-purpose and semi-submersible ships [3, 16, 17]. Yacht shipping is highly specialised and requires technical expertise and equipment. Loading, discharging, and lashing/ securing operations need engineering supervision to ensure that the cargo is transported safely.

Economic and technical factors affect the voyage cost in shipping and are given in $[18,19]$. Daily fixed costs (running costs) should be considered 
while assessing the voyage-based economic efficiency of a ship [20]. This cost is not related to bunker and port costs. It includes crew wages for seamen and office staff, stores, lubricants, repairs, insurance, registration, and management [20]. These costs should be added on top of the voyage expenses after consideration of the total duration of the voyage. Those technical factors are analysed in terms of the ship's speed, sailing time, cargo handling time, ship's deadweight (DWT), cargo stowage plan, and requirements of technical equipment for the cargo.

\section{METHODOLOGY}

In this paper, yacht transfer costs are estimated using two scenarios. Scenario 1 computes the unit carrying cost of a sample yacht by a selected sample ship between Bodrum and Haydarpaşa Ports. Scenario 2 computes the sailing cost of a yacht for the same origin and destination ports to compare the results with scenario 1 .

Two steps of the methodological framework in this study (see Figure 1) show the comparison of the ship voyage and yacht sailing costs. The voyage cost is formulated accounting for all official tariffs and regulations. The code is written in MatLab for the expenses of a ship and yacht at the same origin and destination ports to compare the costs. The voyage costs of a ship are computed for the selected ship as given in Section 2.2. Yacht sailing costs between the origin and destination ports are calculated in accordance with the selected sample yacht model in Section 2.3.

The methodological approach of this study provides an easier computation of the voyage cost and a comparison of the yacht's sailing cost.

\subsection{Study area}

The region of the yacht loading and discharging ports has been selected considering the seasonal change of yacht tourism intensity along the Turkish coasts. This seasonal condition plays a major role in the determination of the loading and discharging ports. For this reason, at the end of the summer season, a loading port in the south of the Aegean and a discharging port in the Marmara Sea region are the most suitable areas to choose to meet the demand of yacht carrying. Moreover, the greater Istanbul area is the best location for the port of discharge, due to the large number of cargo terminals and marinas in the Marmara Sea [21].

The other criteria for the selection of the ports include the geographical location of the port, the depth of the port, the length of its berths, marine traffic in the area, and port service prices. For yachts, being handled at a port within a bay is preferable because yacht handling operations require sensitivity and wave effects on the shore should be minimal. The depth of the port and the length of the berths should be appropriate to the specifications of the selected ship. Marine traffic in the port area may also affect cargo handling operations.

Within this framework, Bodrum has been selected as the most suitable port of loading and Haydarpaşa as the port of discharge. The Voyage Planner in the Marine Traffic Programme has been used to compute the distance between the origin and destination ports. The distance between Bodrum and Haydarpaşa Ports is calculated as $399.8 \mathrm{~nm}$ [22].

\subsection{Ship selection criteria}

The selection of a ship for yacht carrying between these Turkish ports is limited by management/legal/ administrative and technical criteria. The only legal criterion is that the ship should be operating under a Turkish flag in accordance with the 'Cabotage act' in Turkey [23]. The building year, availability of a ship's crane and its capacity, cargo capacity, and bow thruster availability are the technical criteria. Both affect the cost of the voyage. In this framework, General Cargo or Multipurpose Cargo Ships are those that would be suitable for the transportation of yachts as cargo, as they are designed for flexibility while carrying a wide variety of cargo. The building year of the ship is a significant criterion because new ships have lower risks of accidents and technical problems and reduce the insurance expenses. Cargo crane persistence and capacity is the other important criterion because it can reduce or eliminate expenses required for a shore crane. The types of cargo hold should be suitable for the yachts to be carried and bow thruster persistence in a ship provides an advantage on berthing/unberthing costs in accordance with port regulations [24].

Under these circumstances, specifications of the ship M/V TBN (motor vessel to be nominated) are given in Table 1, whereas Figure 2 shows the dimensions of box type cargo holds. 
Ülker D, Koldemir B. Comparative Voyage-Based Evaluation of Yacht Transfer by Self-Sailing and Cargo Vessel Shipment - A...

Scenario 1

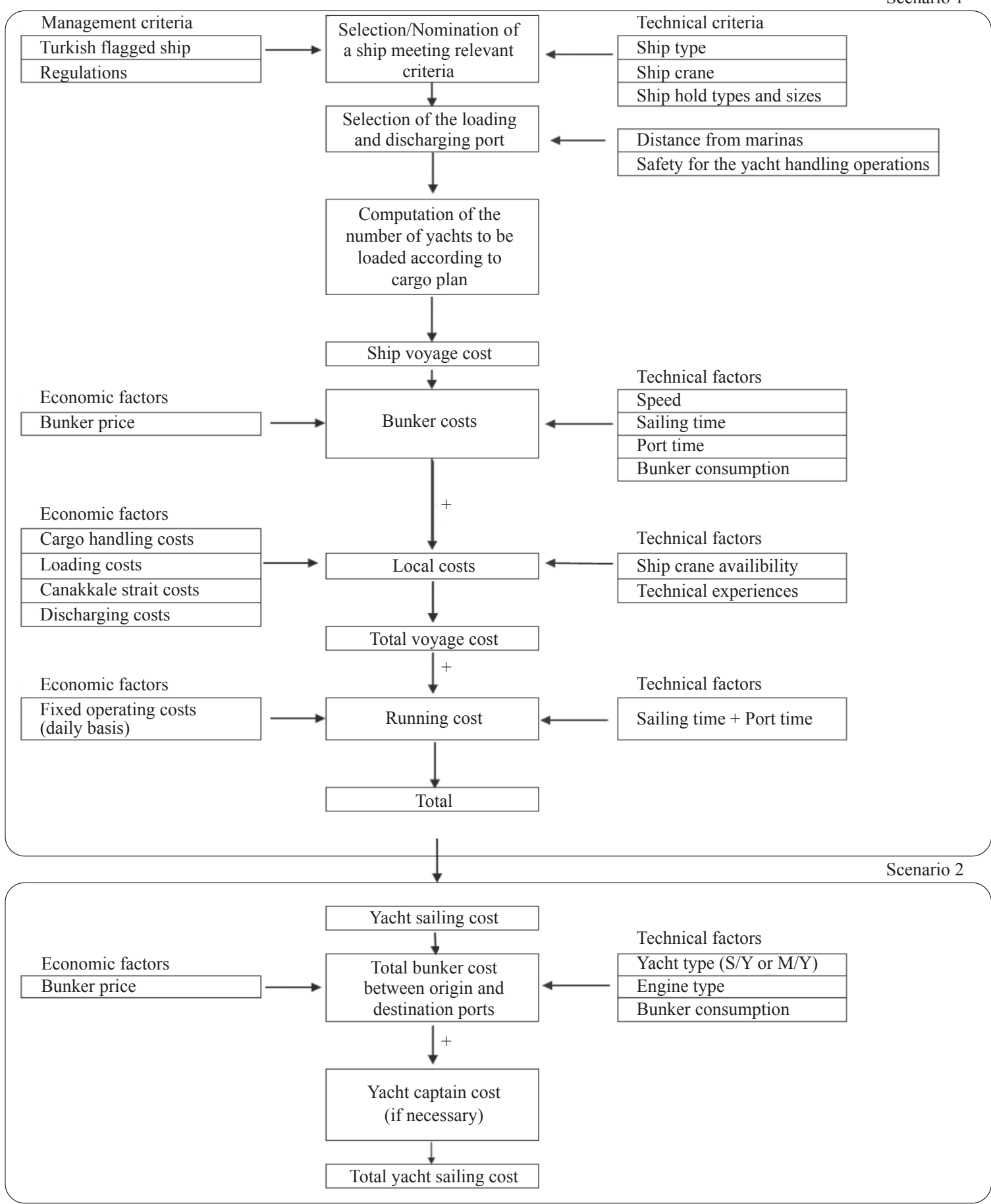

Figure 1 - The methodological framework of the voyage cost estimation (Scenario 1 and Scenario 2)

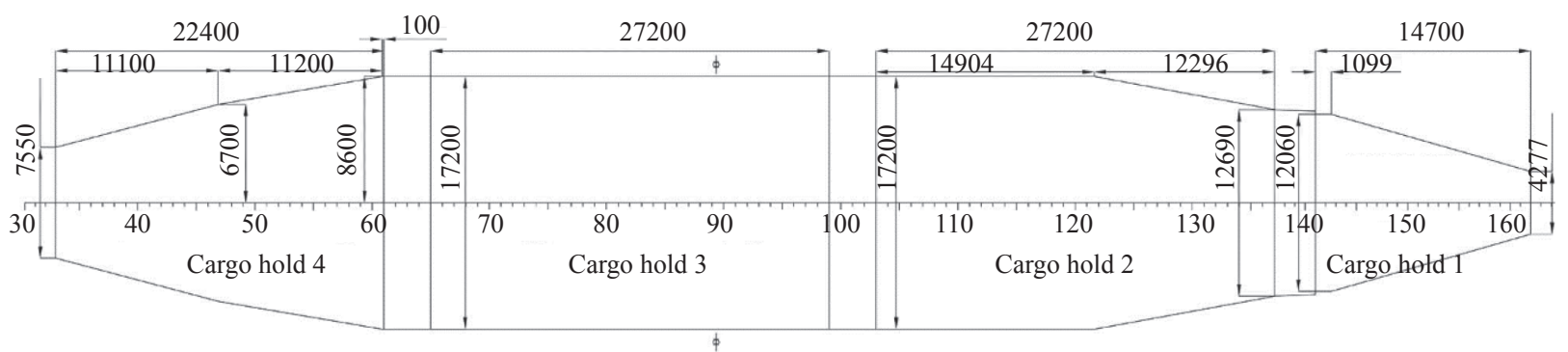

Figure 2-Cargo holds including dimensions of the selected ship 
Ülker D, Koldemir B. Comparative Voyage-Based Evaluation of Yacht Transfer by Self-Sailing and Cargo Vessel Shipment - A...

Table 1 - Specifications of the selected ship model

\begin{tabular}{|c|c|}
\hline Ship name & $\mathrm{M} / \mathrm{V}$ TBN \\
\hline Ship type & $\begin{array}{l}\text { Multi-purpose } \\
\text { general cargo }\end{array}$ \\
\hline Flag & Turkish \\
\hline GT/NT & $9490 / 4603$ \\
\hline DWT & 14883.83 \\
\hline Draft & 9 \\
\hline Length overall (LOA) & 143.41 \\
\hline Breadth & 21.7 \\
\hline Bowthruster [kW] & 450 \\
\hline Number of holds & 4 \\
\hline Type of hold & Box shape \\
\hline Hold No $1\left[\mathrm{~m}^{2}\right]$ & 150 \\
\hline Hold No $2\left[\mathrm{~m}^{2}\right]$ & 440.11 \\
\hline Hold No $3\left[\mathrm{~m}^{2}\right]$ & 467.84 \\
\hline Hold No $4\left[\mathrm{~m}^{2}\right]$ & 330 \\
\hline Weather deck $\left[\mathrm{m}^{2}\right]$ & 1360 \\
\hline Number of deck cranes & 3 \\
\hline Cargo cranes & $3 \times 30 \mathrm{M} / \mathrm{T}$ \\
\hline Speed $[\mathrm{kn}]$ & 13 \\
\hline MDO consumption T/day & 15 \\
\hline MDO consumption at the port T/day $\left(k_{1}\right)$ & 0.7 \\
\hline $\begin{array}{l}\text { MDO consumption at the port by } 3 \\
\text { cranes T/day }\left(k_{2}\right)\end{array}$ & 1.4 \\
\hline
\end{tabular}

Table 2 - Specifications of the sample yacht [25, 26]

\begin{tabular}{||l||l||}
\hline Brand & Revolver 44 GT \\
\hline LOA & 13.09 \\
\hline Bmax & 3.52 \\
\hline Engine & $2 \times$ Cummins QSB 6.7 550 hp \\
\hline Vmax & More than 50 kn \\
\hline Fuel tank capacity & $2 \times 6001$ \\
\hline Fuel Type & Diesel \\
\hline \hline \multicolumn{2}{||c||}{ Bunker consumption performance values } \\
\hline RPM and speed & Bunker consumption $(1 / \mathrm{h})$ \\
\hline $1000 \mathrm{rpm} 7,6 \mathrm{kn}$ & 22 \\
\hline $1500 \mathrm{rpm} 8,6 \mathrm{kn}$ & 50 \\
\hline $2000 \mathrm{rpm} 9,0 \mathrm{kn}$ & 77 \\
\hline $2500 \mathrm{rpm} 9,5 \mathrm{kn}$ & 106 \\
\hline $3000 \mathrm{rpm} 48,5 \mathrm{kn}$ & 196 \\
\hline
\end{tabular}

A stowage plan of the selected ship that meets the cargo hold dimensions given in Figure 2 should be prepared.

In this study, we selected a sample yacht. For the purpose of this study, it is accepted that the ship is loaded with identical yachts. The ship can load a maximum 50 identical yachts considered the cargo holds dimensions in Figure 2. Consequently, the estimations are according to the loading from 1 to 50 yachts. The yacht's sailing cost is then compared with the ship's total voyage cost, calculated to reflect the cost per yacht carried. The yacht carrying capacity is evaluated considering the dimensions of the ship's cargo holds and yacht's dimensions and weight.

\subsection{Sample yacht model}

A sample yacht model is indicated in the study in order to compare the yacht carrying cost and yacht sailing cost. In general, there are two types of yachts: motor yachts $(\mathrm{M} / \mathrm{Y})$ and sailing yachts $(\mathrm{S} / \mathrm{Y})$. Table 2 shows the specifications of the selected sample model, which is a motor yacht $[25,26]$. In scenario 1 , the carriage cost for a single unit of this model, between Bodrum and Haydarpaşa, is estimated considering the number of yachts carried. Cost changes depending on the selected ship's cargo plan and the number of yachts that are carried.

\subsection{Voyage cost estimation for the selected ship model (Scenario 1)}

The voyage cost depends on all of the economic and technical factors mentioned above (see Figure 1). In the calculation of the voyage cost, we considered the selected ship's specifications, IMO regulations, port regulations, port tariffs, and other related official fees of the organisation. The following equations are written in MatLab and the graph of function is plotted for different variables. The formula of the voyage cost for the selected loading and discharging port and cargo is applied as given in Equations 1 and 2 .

\section{Computation of voyage time}

Voyage time depends on time spent during sailing $\left(T_{s}\right)$ and loading and discharging in ports $\left(T_{p}\right)$.

$$
T=T_{s}+T_{p}
$$

Sailing time is time spent (in days) by the ship depending on the speed $\left(V_{s}\right)$ and distance $(D)$ between the loading and discharging ports. 


$$
T_{s}=\frac{D}{V_{s} \cdot 24}
$$

\section{Computation of port time}

$T_{p}$ depends on the cargo handling process and the amount of cargo, and is the sum of time spent (days) in discharging port $\left(T_{d}\right)$ and loading port $\left(T_{l}\right)$. Weather conditions, mechanical problems, custom clearances, and the experience of crane operators also cause a lot of uncertainty when estimating port time. In this paper the relation between port time $\left(T_{p}\right)$ and the number of yachts carried $(y)$ is accepted to be a linear association as given in Equations 3-5 and Figure 3.

$$
\begin{aligned}
& T_{p}=T_{d}+T_{l} \\
& T_{d}(y)=0.075 \cdot y+\frac{4}{24} \\
& T_{l}(y)=0.125 \cdot y+\frac{4}{24}
\end{aligned}
$$

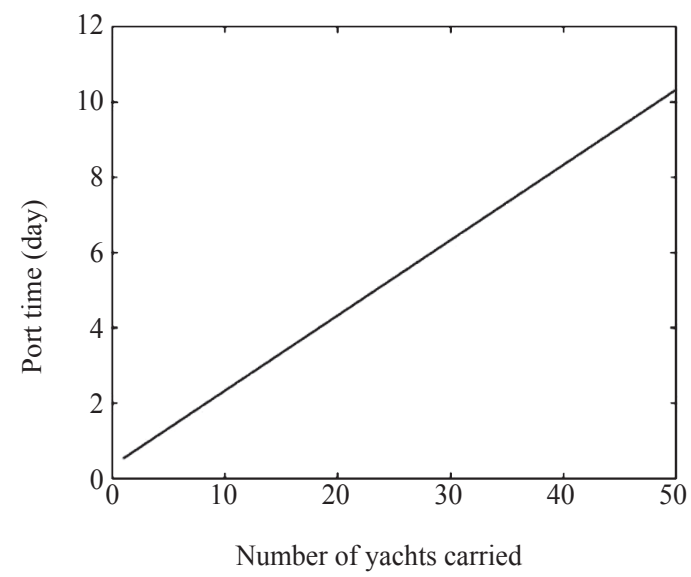

Figure 3 - Total staying time in loading and discharging port

\section{Computation of running cost}

Running cost $(\mathrm{RC})$ is related to the daily requirements for crew wages, maintenance and repairs, insurance, administrations costs, and proportional costs [18]. Grainer (2017) studied benchmarking of operational costs including the variance of running costs according to ship type. It is indicated that the running costs for an average handysize bulk carrier, aged 16-25 years, is USD 5,147 [27]. A ship management company calculated a running cost of about USD 3,700 per day for that selected ship. This amount can be applied in this study since the size of our selected ship is lower than the average size of a handysize ship. Running cost expenses during the voyage $\left(R C_{v}\right)$ (USD) are obtained by multiplying daily costs by total voyage time $(T)$ in Equation 6 .
$R C_{v}=R C \cdot T$

\section{Computation of bunker cost}

According to the IMO sulphur regulation 2020, bunker suppliers may not sell high sulphur fuel oil for use on domestic voyages. Consequently, in domestic shipping, only marine gas oil supply is applicable. The marine gas oil price was received from a bunker company on the 30 January 2020. Although this cost is exempt from special consumption tax, VAT is included. The bunker cost on the voyage depends on bunker consumption during sailing and port time. Bunker consumption during port time depends on cargo handling and unworking time, because bunker consumption increases while the ship's cranes are being operated. We calculated bunker consumption costs in line with the technical details given by the ship-owner.

Bunker cost (BC) is formulated in Equation 7 considering bunker consumption during sailing $\left(B_{s}\right)$ (Equation 8), bunker consumption during port stay $\left(B_{p}\right)$ (Equation 9$)$, and bunker price $\left(P_{b}\right)$. Division to $r_{d t}$ is inserted to show the result in USD.

$B C=\frac{\left(B_{s}+B_{p}\right) \cdot P_{b}}{r_{d t}}$

$B_{s}=15 \cdot T_{s}$

$B_{p}=k_{1} \cdot T_{p} \cdot 0.375+k_{2} \cdot T_{p} \cdot 0.625$

where, $k_{1}$ and $k_{2}$ are the ship specific coefficients for the bunker consumption in port staying.

\section{Computation of Çanakkale Strait light due} in Turkish Cabotage

The light due tariff depends on the vessel's net tonnage $(N)$ [28]. Light due $\left(D L D_{i}\right)$ tariff is formulated as in Equation 10 and the currency is USD for the Çanakkale Strait passage. Light dues are charged to ships for the maintenance of lighthouses and other navigational aids.

$D L D_{i}(N)=800 \cdot 0.06+(N-800) \cdot 0.03$

This formula gives the cost of Çanakkale Strait light due for the single passage of a general cargo ship which works on a domestic line.

\section{Computation of Port Call Expenses}

Port call expenses can be divided into two groups, one of which is services by port that are paid to the port and the other is costs that are paid to other official or private organisations serviced by them. The formulas calculating official tariffs of ports and the 
other organisations are shown below. Formulas are implemented for the Bodrum and Haydarpaşa Port, respectively.

Bodrum Port expenses: The handling of a yacht in Bodrum anchorage takes place with the permission of the Harbour Master of Bodrum. The formulas of each cost are given in Equations 11-19 in accordance with the current regulations in 2020 [24, 28-31]. Expenses to be charged in the Bodrum Anchorage $\left(E_{l}\right)$ are the sum of harbour master due $(h)$, sanitary due $(H)$, portlight due $\left(P L D_{i o}\right)$, chamber of the shipping dues $(C)$ [32], agency fee $(a)$, motor service fee $(M)$, waste fee $(w)$ [31], lashing fee $(l)$, and custom overtime fee $(c)$ [30].

$$
\begin{aligned}
& E_{l}=h+H+P L D_{i o}+C+a+M+w+l+c \\
& h=288 / r_{d t} \\
& H=\left(N \cdot 2.73 \cdot T / r_{d t}\right) / 365 \\
& P L D_{i o}=[800 \cdot 0.0336+(N-800) \cdot 0.0168] \cdot 2 \\
& C=685 / r_{d t} \\
& M=y \cdot 100 \\
& w=210 \cdot r_{e d} \\
& a=a_{t} \cdot r_{e d}, \text { if } 4000<N \leq 5000, a_{t}=1450 € \\
& l(y)=y \cdot 500
\end{aligned}
$$

This applies where $E_{l}$ is loading port expenses (USD), $N$ is the net tonnage of the ship, $y$ is number of yachts loaded, $r_{d t}$ is the rate between USD and TL, $r_{e d}$ is the rate between Euro and USD, $c$ depends on the period of ship's operations.

Haydarpaşa Port expenses: Haydarpaşa port is in an easily accessible location for yacht owners. The port is governed by the Turkish Republic State Railway (TCDD). Turkish port tariffs categorise the yacht cargo category differently from the project cargo category. The tariff defines the project cargo as the heavy weight and heavy size cargoes except when dealing with yachts, for which the cost for the project cargo is USD 4/ton in Haydarpaşa while the yacht handling cost is USD 1020/yacht for the yachts between 0 and 20 tons. A $50 \%$ discount is applied to this tariff if the cargo handling operation is carried out by ship's equipment and crew. Official tariffs paid to the port are set by the TCDD. Expenses to be charged in Haydarpaşa $\left(E_{d}\right)$ are calculated with Equations 20-26 in accordance with the official tariffs [33]. These expenses are pilotage in/out $\left(P_{i o}\right)$, tugboat in/out $\left(T_{i o}\right)$, mooring boat costs $(m)$, berth due $(b)$, portlight due $\left(P L D_{i o}\right)$, chamber of shipping dues $(C)$, custom overtime $(c)$ [30], agency fee $(a)$ [34], motor service $(M)$, and discharging fee $\left(D_{f}\right)$ (TCDD, 2020).

$$
\begin{aligned}
& \begin{array}{l}
E_{d}=P_{i o}+T_{i o}+m+b+H+w+h+P L D_{i o}+c+C \\
\quad \\
\quad M+a+D_{f}
\end{array} \\
& P_{i o}(G)=(G \cdot 22+60) \cdot 2 \\
& T_{i o}(G)=[(G \cdot 20+85) \cdot 2] \cdot 0.5 \\
& m(G)=(G \cdot 24.50+49) / r_{d t} \\
& b(G)=(17.50+G \cdot 17.50) \cdot T_{d} / r_{d t} \\
& P L D_{i o}(N)=[800 \cdot 0.0336+(N-800) \cdot 0.0168] \cdot 2 \\
& D_{f}(y)=510 \cdot y, 0<y \leq 50
\end{aligned}
$$

This applies where $E_{d}$ is discharging port expenses (USD), $G$ is the gross tonnage of the ship, $N$ is the net tonnage of the ship, $y$ is the number of yachts loaded.

\subsection{Sailing costs for the selected sample yacht model (Scenario 2)}

In this part of the study, sailing costs for the selected sample yacht (see Table 2) through the route computed in Section 2.1 are calculated. The sailing costs include the bunker cost and yacht captain fee. Yacht captain appointment depends on the preference of the yacht owners. They may choose to hire an experienced yacht captain to transport their yacht from the south to the north of Turkey due to the long sailing time. The owners may prefer yacht captain appointment considering the below factors; (i) weather conditions, (ii) Çanakkale Strait passage, (iii) long-distance, (iv) sailing experience, and (v) time.

The formulas of the yacht sailing costs are given below in Equations 27-30.

$$
\begin{aligned}
& T Y S_{c}=B C_{y}+Y C \\
& t_{y s}=D / V_{y} \\
& B_{y s}=D \cdot C_{y} \\
& B C_{y}=B_{y s} \cdot P_{b}
\end{aligned}
$$

where $T Y S_{c}$ is the total yacht sailing cost (USD), $B C_{y}$ is the yacht bunker cost (USD), $Y C$ is the cost of a yacht captain, $t_{y s}$ is the total yacht sailing time 
(hours), $D$ is the distance between the origin and destination ports (nmi), $V_{y}$ is the yacht's speed, $B_{y s}$ is the bunker consumption of the yacht (litres), $C_{y}$ is the rate of bunker consumption for a specific speed as given in Table 2, and $P_{b}$ is the bunker price (USD).

\section{RESULTS AND DISCUSSION}

Considering the yachting activity between the Marmara and Aegean coasts in the summer and autumn periods, yachting risks are higher due to weather conditions and difficulty of passing through the Çanakkale Strait, especially for the yachts that want to move from the Aegean coasts to the Marmara in the autumn.

All of the possible expenses are considered for yacht carrying by a cargo ship and each cost is formulated as a function. These functions given in Section 2 are written in MatLab. Figure 4 gives the results of unit costs of six categories per yacht carried. The unit costs' graphs of running cost, bunker, loading port, discharging port, and Çanakkale Strait are non-linear C-Curves since some of the huge expenses are fixed costs incurred for a voyage, while the others slightly increase with the amount of cargo carried. However, the graph of cargo insurance unit cost per yacht is a constant curve since it is computed the same way for each yacht.

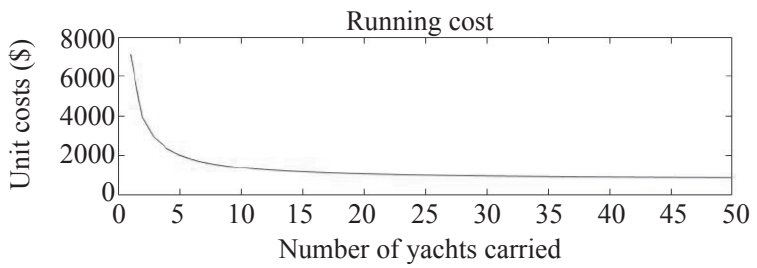

Loading port

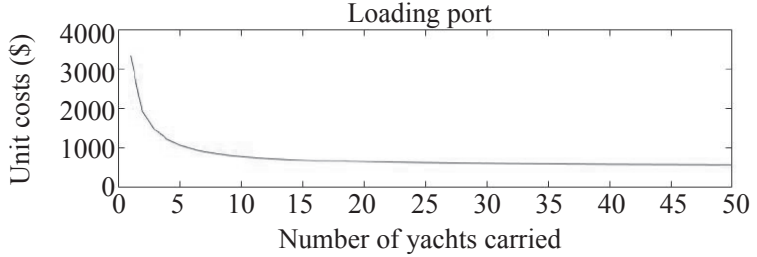

Canakkale Strait

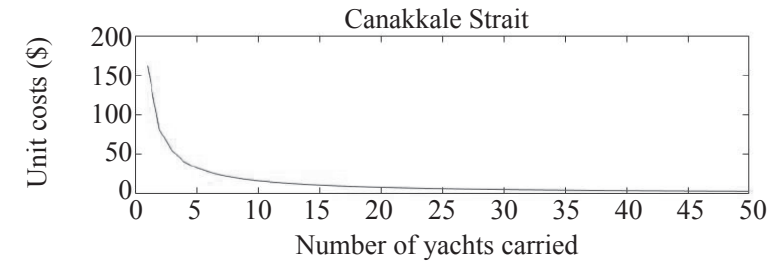

In the light of the above costs, the total voyage cost graph, which is a non-linear C-curve, is given in Figure 5. Unit cost decreases with a non-linear C-curve depending on the number of yachts carried. These results indicate the optimum amount of yacht carrying. The unit cost difference rates between 1 yacht and $4,7,10,20,30$, and 40 yachts are $68.7 \%, 78.6 \%, 82.5 \%, 87.6 \%$, and $88.6 \%$, respectively. These results reflect that the decreasing rates of more than seven yachts are slight. It can be seen that the ship-owner should fix more than seven yachts for a voyage to offer an acceptable price for yacht owners. Figure 5 gives the results of the costs for a ship-owner. However, it is surely beyond doubt that the ship-owner's profit will be added to these prices. The profit rate can be arranged depending on the number of yachts carried in a voyage.

It is also noteworthy that the carrying of yachts by ships will reduce the congestion in the Turkish Straits System. This may reduce the risk of accidents in the region $[35,36]$.

In Figure 6, we present the amount of bunker consumption (a), bunker cost (b), and total yacht sailing cost (c) for the Bodrum-Haydarpaşa route depending on the yacht's speed. If the yacht navigates at eco-speed, the total bunker cost is USD 1352 and the total yacht sailing cost USD 2352. If it navigates with a speed greater than $7.5 \mathrm{knots} / \mathrm{h}$, these costs will increase considerably. For in-

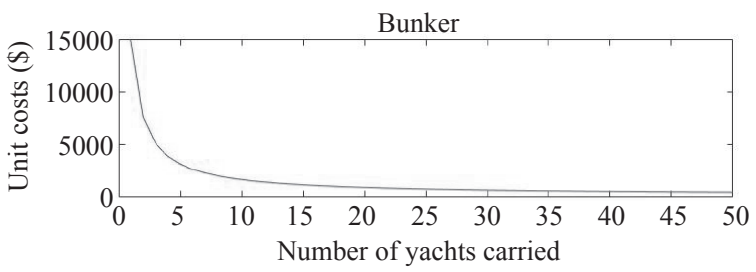

Discharging port

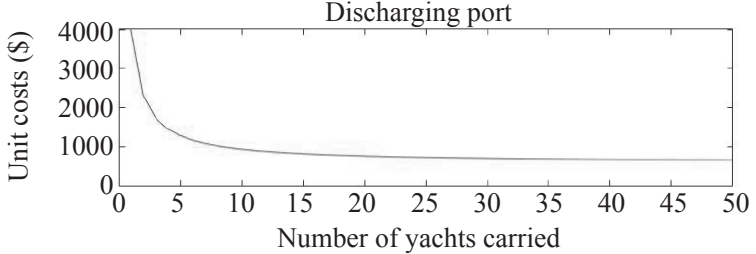

Cargo insurance

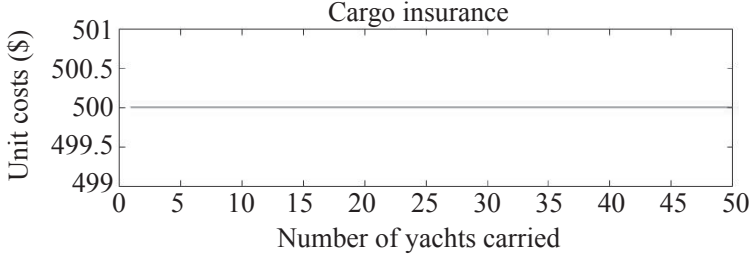

Figure 4 - The unit costs of the expenses 
stance, when travelling 9.5 knots/h the bunker cost is USD 5213. Clearly if a sailing yacht is being used, the costs in Figure 5 would be even lower. For non-sailing yachts, slight increases of the yacht's speed cause extreme increases in bunker consumption and bunker costs. These costs will increase if the engine type is a petrol engine instead of diesel. Comparing the prices given in Figures 5 and 6, we indicate that the payment of yacht carrying costs between the Bodrum and Haydarpaşa ports can be worthwhile considering time, distance, and risk factors. However, owners should load the maximum number of yachts on a voyage to offer acceptable prices to yacht owners.

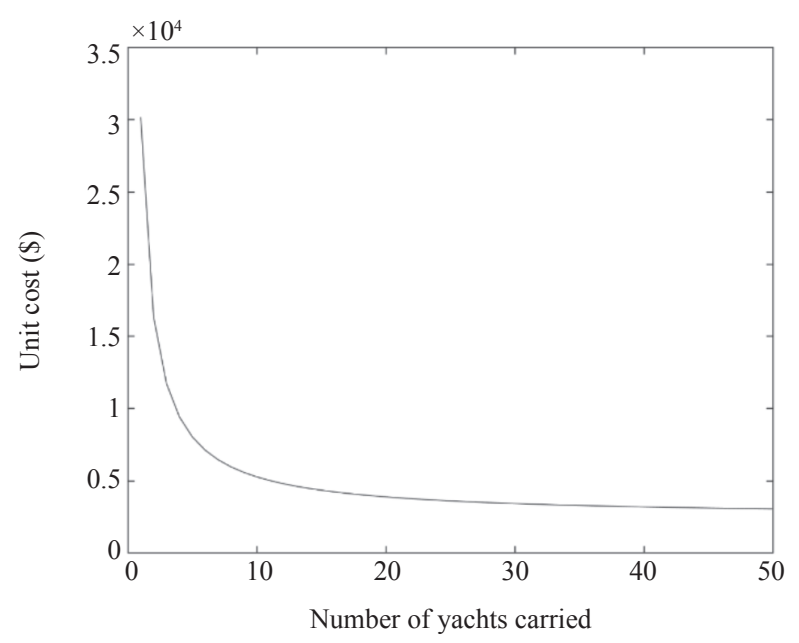

Figure 5 - The unit voyage cost per yacht carried
As seen in Figure 6, the fuel consumption increases depending on the yacht's speed and consequently, exhaust gas emissions increase accordingly. This also affects the air and sea water quality in the region $[37,38]$.

The formulas written in MatLab and implemented between the selected ports can be developed for other ports to estimate the cost efficiency compared to yacht sailing. They can also be developed for shipping other types of cargo in order to compute the lump sum costs more easily for the shipment. This methodology provides an easier approach for cost-benefit analysis studies.

\section{CONCLUSION}

Turkey, with its long coastline, has the potential for yacht carrying on a domestic shipping line as well as international yacht shipping. This is particularly true in the coastal areas of Turkey where there is a high amount of yacht tourism. Such a seasonal multiple yacht carrying service by a cargo ship in Scenario 1 has never been applied in practice by domestic shipping lines in Turkey. This paper indicates a new cargo option for Turkish flagged ship-owners and international ship chartering companies. Moreover, this paper offers a new transport alternative for yacht owners between Turkish ports and highlights how yacht carrying on a domestic shipping line can be feasible for yacht owners and ship-owners.
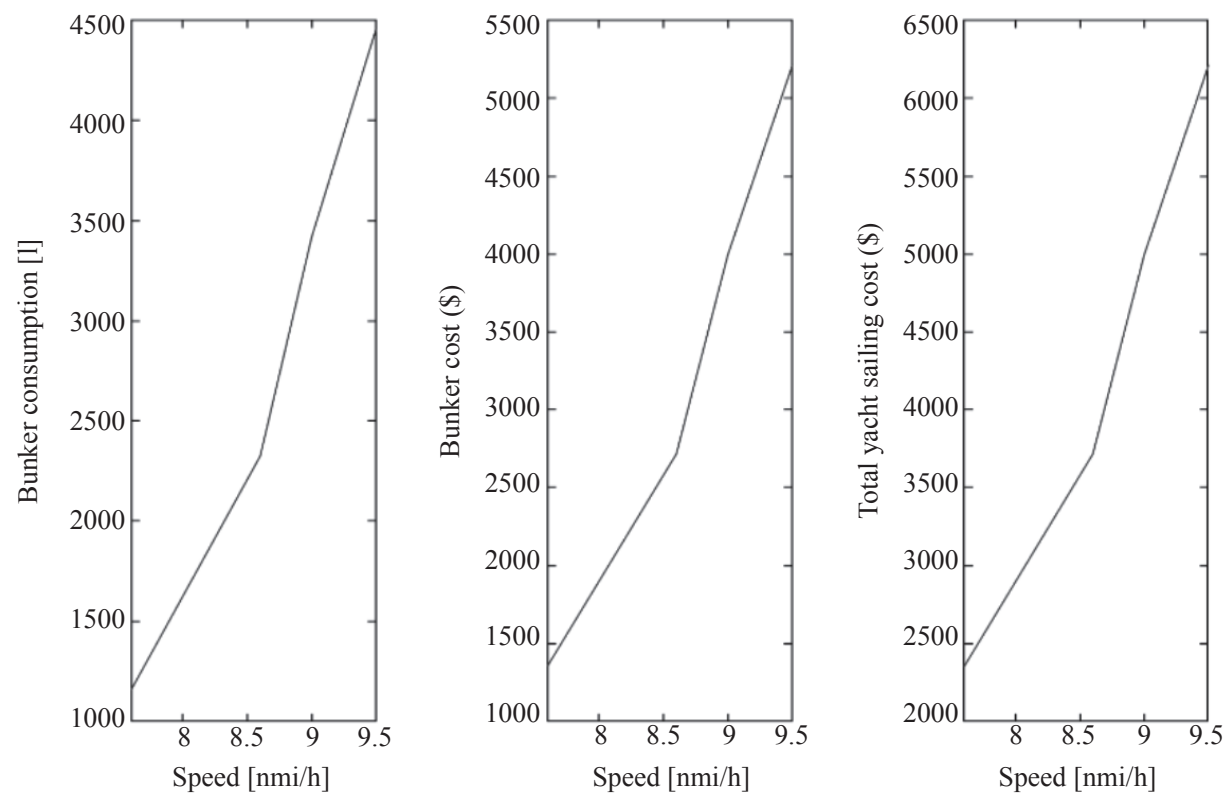

Figure 6 - Amount of the bunker consumption, bunker cost, and total yacht sailing cost for the Bodrum-Haydarpaşa route depends on the yacht's speed 
Given the above, this study emphasises the following:

- The carrying of yachts in international shipping is managed efficiently by some ship-owners in different parts of the world. The long coastline of Turkey also offers the potential for yacht carrying on domestic shipping lines.

- Port selection criteria for yacht carrying in domestic shipping should factor in the main direction of seasonal yacht tourism in the region.

- The specifications of the cargo ship are of great importance in terms of cargo capacity and the availability of a crane, in order to minimise costs.

- The estimated cost of yacht carrying between the Bodrum and Haydarpaşa Ports can be acceptable to owners, depending on the yacht types and the number of yachts carried.

- The applied model lists requirements for the minimum number of yachts to be loaded for cost efficiency. In scenario 1, in which the yachts are transported by a cargo ship between Bodrum and Haydarpaşa ports, transportation should be carried out for a minimum of 7 yachts and above, depending on the occupancy of the ship.

- In scenario 2, if the same route is completed by a yacht (the model of which is listed in the example), the passage through the Çanakkale Strait, distance, and long sailing times can cause some navigational risks. In addition to these disadvantages, it is determined that the travel cost increases depending on the yacht's speed. If a captain appointment is necessary, the cost of the voyage becomes too high. To avoid the costs in Scenario 2 and to reach the Sea of Marmara more safely, it is recommended that yacht owners choose scenario 1.

- The applied voyage-based model shows the feasibility of yacht carrying along this route. As a new decision support tool, it can be modified easily to other ship and cargo types and also to other ports, accounting for their official fees.

- It is suggested that a seasonal yacht carriage service should be implemented between the South and Marmara coasts of Turkey by Turkish ship-owners or by international ship chartering companies.

This study aimed to show the appropriate ship type for cost-effective yacht carrying on the domestic shipping line. One of the criteria is having a ship's crane to avoid extra shore crane expenses, which affect the total voyage cost, and multi-pur- pose general cargo ships are suitable for this criterion. As is usual in shipping practice, it is better practice to use the ship's crane (if it has enough carriage capacity) for operational and financial efficiency. Consequently, the cost differences between usage of the ship's crane and port's crane have not been included in this paper.

The other limitation of this paper is depiction of time spent in the port as linear. Time spending in ports (Tp) depends on many factors such as weather conditions, amount of cargo, experience of the crane operator and ship's crew, customs clearance, and mechanical problems. Only the following factors are considered in the formula: the number of yachts carried, coefficients of the loading and discharging period, and fixed time for customs clearance.

For future research, an extension of this study with questionnaires that will be applied to the yacht owners around Istanbul would be useful. This is necessary to understand the specifications of their yachts and the quantitative potential of yacht carriage. Also, other potential routes should be determined with questionnaires and their cost efficiency should be evaluated. One other open issue is the evaluation of emissions while yacht-carrying which are produced by a domestic line along this route.

DUYGU ÜLKER, Ph.D. Aday $1^{1}$

E-mail: duygu.ulker@istanbul.edu.tr

BİRSEN KOLDEMIR, Ph.D. ${ }^{2}$

(Yazışmadan sorumlu yazar)

E-mail: bkr@iuc.edu.tr

${ }^{1}$ Denisel Çevre Anabilim Dalı

Deniz Bilimleri ve İşletmeciliği Enstitüsü

İstanbul Üniversitesi

No.17, Müşküle Sokak, 34134, Vefa-Fatih/Istanbul, Turkey

2 Deniz Ulaştırma İşletme Mühendisliği Bölümü

Mühendislik Fakültesi

İstanbul Üniversitesi-Cerrahpaşa

34320, Avcilar/Istanbul, Turkey

\section{YAT TRANSFERININN KENDİ SEYRI VE YÜK GEMISIYYLE NAKLININ KARŞILASTTIRMALI SEFERBAZLI DEĞERLENDIRILMESI - BÍR PILOT CALISMA \\ ÖZET}

Türkiye'de sezonluk yat trafiği dahili seferlerde yaz aylarında Marmara kiyllarından güney kiyılarına doğru yönelim göstermekte ve yaz sonu/sonbahar başl ise zıt yönde trafik meydana gelmektedir. Sezonluk yat taşınım rotaları boyunca uzun mesafe ve uzun seyir süresi dikkate alındığında, bu çalışma dahili seferde yat taşımacıllı̆ıııın yat sahipleri ve gemi armatörleri açısından uygulanabilir olup olmadı̆̆ını ortaya koymaktadır. Yat 
taşımacılı̆̆ında liman ve gemi seçim kriterleri iki grup olarak belirlenmiştir: teknik kriterler ve işletme kriterleri. Hesaplamalar seçilen gemi ve yat modeline ve seçilen yükleme/tahliye limanlarına göre yapılmıştır. Tüm sefer masrafları formülleştirilmiştir ve MatLab'da yazılmıştır. Örnek geminin ve yat modelinin sefer masrafi Bodrum ve Haydarpaşa limanları arasında yat taşımacılı̆̆ının uygulanabilirliğini değerlendirmek için hesaplanmıştır. Yat taşımacılığının bu limanlar arasında uygulanabilir olması taşınan yat sayısına, yatların hızına, yat tipine göre değişmektedir. Türkiye'deki uzun kıy şseridi ve mevcut yat potansiyeli dahili seferlerde yat taşımacılı̆̆ının elverişli bir uygulama olduğunu göstermektedir.

\section{ANAHTAR KELIMELER}

Verimlilik; Deniz taşımacılığl; Sefer masrafi; Yat taşımacılı̆̆ $ı$; Yat trafiği.

\section{REFERENCES}

[1] Karanci A, Guler I, Ergin A, Yalciner AC. Demand forecasting for yacht tourism planning in Turkey. Proceedings of Coastal Engineering Practice; 2011. p. 1078-1087. DOI: 10.1061/41190(422)87 [Accessed 6th May 2020].

[2] Sariisik M, Turkay O, Akova O. How to manage yacht tourism in Turkey: A SWOT analysis and related strategies. Procedia - Social and Behavioral Sciences. 2011;24: 1014-1025. DOI: 10.1016/j.sbspro.2011.09.041 [Accessed 15th Jan. 2020].

[3] Dernek D, Koldemir B. A study about transportation of yachts by ships: Case study Haydarpaşa-Fethiye. Proceedings of the $3^{\text {rd }}$ National Marine Tourism Symposium, Izmir, Turkey; 2016. DOI: 10.18872/ DEU.b.UDTS.2016.0011 [Accessed 29th Nov. 2019].

[4] GencEP, GulerN.Assessment of Marinas in the Mediterranean and the Position of Turkey. Promet - Traffic\&Transportation. 2006;18(3): 207-213. Available from: http:// traffic.fpz.hr/index.php/PROMTT/article/view/688 [Accessed 29th Nov. 2019].

[5] Kalemdaroglu AE, Seker DZ, Kabdasli S. GIS based inventory of marinas on the coastal region of Turkey. Proceedings of the XXth ISPRS Congress, 12-23 July 2004, Istanbul, Turkey; 2004. p. 12-23. Available from: https:// www.isprs.org/proceedings/XXXV/congress/comm7/ papers/62.pdf [Accessed 29th Nov. 2019].

[6] Spliethoff Group. World Ocean Transport. Amsterdam; 2020. Available from: https://www.spliethoffgroup.com/ assets/data/spliethoff-group-brochure-january-2020. [Accessed 29th Oct. 2020].

[7] MTI. Official Maritime Statistics of the Ministry of Transport and Infrastructure. Turkey Ministry of Transportation and Infrastructure; 2020. Available from: https:// atlantis.udhb.gov.tr/istatistik/istatistik_yuk.aspx\%0A. [Accessed 5th Oct. 2020].

[8] Kapidani N, Tijan E, Jović M, Kočan E. National maritime single window-cost-benefit analysis of Montenegro case study. Promet - Traffic\&Transportation. 2020;32(4): 543-57. DOI: 10.7307/ptt.v32i4.3422 [Accessed 14th Oct. 2020].

[9] Burak S, Dogan E, Gazioglu C. Impact of urbanization and tourism on coastal environment. Ocean \& Coastal Management. 2004;47(9-10): 515-527. DOI: 10.1016/j. ocecoaman.2004.07.007 [Accessed 15th Jan. 2020].

[10] Koc E, Altinay G. An analysis of seasonality in monthly per person tourist spending in Turkish inbound tourism from a market segmentation perspective. Tourism Management. 2007;28(1): 227-237. DOI: 10.1016/j.tourman.2006.01.003 [Accessed 15th Jan. 2020].

[11] Aydoğan E, Kadıŏlu M. The place and importance of yacht tourism in the tourism sector. Journal of ETA Maritime Science. 2018;6(3): 243-254. DOI: 10.5505/ jems.2018.83702 [Accessed 15th Jan. 2020].

[12] Fagerholt K, Hvattum LM, Johnsen TAV, Korsvik JE. Routing and scheduling in project shipping. Annals of Operations Research. 2013;207(1): 67-81. DOI: 10.1007/s10479-011-0888-1 [Accessed 10th Jan. 2020].

[13] Murty KG, et al. DSS (Decision Support Systems) for operations in a container shipping terminal. Proceedings of the First Gulf Conference on Decision Support Systems, Council of Ministers General Secretariat, State of Kuwait; p. 189-208. Available from: http:/www-personal.umich.edu/ murty/kuwait4.pdf [Accessed 10th Jan. 2020].

[14] Murty KG, Liu J, Wan Y, Linn R. A decision support system for operations in a container terminal. Decision Support Systems. 2005;39(3): 309-32. DOI: 10.1016/ j.dss.2003.11.002 [Accessed 10th Jan. 2020].

[15] Fagerholt K. A computer-based decision support system for vessel fleet scheduling - experience and future research. Decision Support Systems. 2004;37(1): 35-47. DOI: 10.1016/S0167-9236(02)00193-8 [Accessed 10th Jan. 2020].

[16] Van Hoorn F. Heavy-lift transport ships - overview of existing fleet. Proceeding of the Marine Operations Specialty Symposium, MOSS-32, Singapore; 2008. p. 1-9. Available from: http://argonautics.us/MOSS $\% 20$ 2008\%20Paper\%2032\%20-\%20Heavy-Lift\%20Transport $\% 20$ Ships $\% 20-\% 20$ Overview\%20of\%20Existing\%20Fleet\%20and\%20Future\%20Developments.pdf [Accessed 13rd Dec. 2019].

[17] Dernek D. [Cost analysis and efficiency of yacht transport in the cabotage line]. MSc. Thesis. Istanbul University; 2016. Available from: https://tez.yok.gov.tr/ UlusalTezMerkezi/tezDetay.jsp?id=kuH4HFOEtK8mil6raNeJ9g\&no=dOMArPR9XhGfJC5prjf69g. Turkish [Accessed 25th Nov. 2019].

[18] Polo G. On maritime transport costs, evolution, and forecast. Cienc y Tecnol Buques. 2012;5(10): 19. DOI: 10.25043/19098642.57 [Accessed 25th Nov. 2019].

[19] Hess M, Hess S. Multi-objective ship's cargo handling model. Transport. 2015;30(1): 55-60. DOI: 10.3846/16484142.2013.791999. [Accessed 25th Nov. 2019].

[20] Počuča M. Methodology of day-to-day ship costs assessment. Promet - Traffic - Traffico. 2006;18: 337-45. DOI: 10.7307/ptt.v18i5.704 [Accessed 2nd Feb. 2020].

[21] Ülker D. Evaluation of short-sea shipping networks in the Sea of Marmara for the earthquake transportation emergency management. $2^{\text {nd }}$ International Disaster \& Resilience Congress, 13-15 Oct. 2020, Eskişehir, Turkey; 2020. p. 231-235. 
[22] Marine Traffic. Voyage Planner 2020. Available from: https://www.marinetraffic.com/en/voyage-planner? panel $=$ on [Accessed 22nd Feb. 2020].

[23] Official Gazzete No. 359. [Cabotage act]. 1926.

[24] Official Gazzete No:28572. [Regulation about Amending the Ports Regulation]. 2013. Turkish.

[25] Revolver. Revolver 44GT 2020. Available from: http:// www.revolverboats.com/products.php? productID $=2$ [Accessed 22nd Oct. 2020].

[26] Boatmag International. 44GT: A good shot for Revolver Boats 2014. Available from: http://www.boatmaginternational.com/780-revolver-44-gt/ [Accessed 22nd June 2020].

[27] Grainer R. Ship operating costs: Current and future trends. 2017. Available from: http://greece.moorestephens.com/MediaLibsAndFiles/media/greeceweb.moorestephens.com/Documents/1-Richard-Greiner.pdf [Accessed 18th May 2020].

[28] Directorate General of Coastal Safety. [Tariff of light and life saving due]. 2019. Turkish.

[29] Official Gazzete No:30991. [Act of fees general communique]. 2019. Available from: https://www.resmigazete. gov.tr/eskiler/2019/12/20191227M2-9.htm [Accessed 17th April 2020] Turkish.

[30] Official Gazzete No:30995. [Custom General Communiquée]. 2019. Available from: https://www.resmigazete. gov.tr/eskiler/2019/12/20191231M4-11.htm [Accessed 17th Apr. 2020]. Turkish.

[31] Official Gazette No:27249. [Notice on fees and principles to be applied in the framework of receipting waste from ships and control of wastes]. 2009. Available from: https:// www.resmigazete.gov.tr/eskiler/2009/06/20090605-10. $\mathrm{htm}$ [Accessed 17th Apr. 2020]. Turkish.

[32] Chamber of Shipping. [Tariff]. 2020. Available from: https://www.denizticaretodasi.org.tr/tr/sayfalar/tarifeler [Accessed 17th Apr. 2020]. Turkish.

[33] TCDD. Port service costs for year 2020:76.

[34] Official Gazette No:26812. Ship Agency Services Fee Tariff. 2008. Available from: https://www.resmigazete. gov.tr/eskiler/2008/03/20080310-2.htm [Accessed 17th Apr. 2020].

[35] Koldemir B. [Determination of risky regions in strait of istanbul from the aspect of navigational safety; updating of the accident black points]. Journal of DEU Maritime Faculty. 2009;1(1): 17-26. Available from: http:// hdl.handle.net/20.500.12397/864 [Accessed 18th May 2020]. Turkish.

[36] Ülker D, Baltaoğlu S. Ship born oil pollution in Turkish Straits Sea Area and MARPOL 73/78. In: Ünlü S, Alpar B, Öztürk B. (eds.) Oil Spill along Turkish Straits Sea Area. Istanbul, Turkey: TUDAV; 2018. p. 363-370.

[37] Koldemir B, Yapıc1 M. [Protection applications of ship-genrated air pollution for reduction in Turkey and the world]. Proceedings of $1^{\text {st }}$ National Ship Traffic Services Congress, Istanbul, Turkey. p. 97-110.Turkish.

[38] Ülker D, Bayırhan İ, Mersin K, Gazioğlu C. A comparative $\mathrm{CO} 2$ emissions analysis and mitigation strategies of short-sea shipping and road transport in the Marmara Region. Carbon Management. DOI: 10.1080/17583004.2020.1852853 